\title{
The Veil in Islam and Randa Abdel-Fattah's Does My Head Look Big in This?
}

\author{
Halimah Mohamed Ali
}

To Link this Article: http://dx.doi.org/10.6007/IJARBSS/v11-i3/8401

DOI:10.6007/IJARBSS/v11-i3/8401

Received: 01 February 2021, Revised: 26 February 2021, Accepted: 05 March 2021

Published Online: 18 March 2021

In-Text Citation: (Ali, 2021)

To Cite this Article: Ali, H. M. (2021). The Veil in Islam and Randa Abdel-Fattah's Does My Head Look Big in This? International Journal of Academic Research in Business and Social Sciences, 11(3), 708-721.

Copyright: (C) 2021 The Author(s)

Published by Human Resource Management Academic Research Society (www.hrmars.com)

This article is published under the Creative Commons Attribution (CC BY 4.0) license. Anyone may reproduce, distribute, translate and create derivative works of this article (for both commercial and non-commercial purposes), subject to full attribution to the original publication and authors. The full terms of this license may be seen

at: http://creativecommons.org/licences/by/4.0/legalcode

Vol. 11, No. 3, 2021, Pg. 708 - 721

Full Terms \& Conditions of access and use can be found at http://hrmars.com/index.php/pages/detail/publication-ethics 


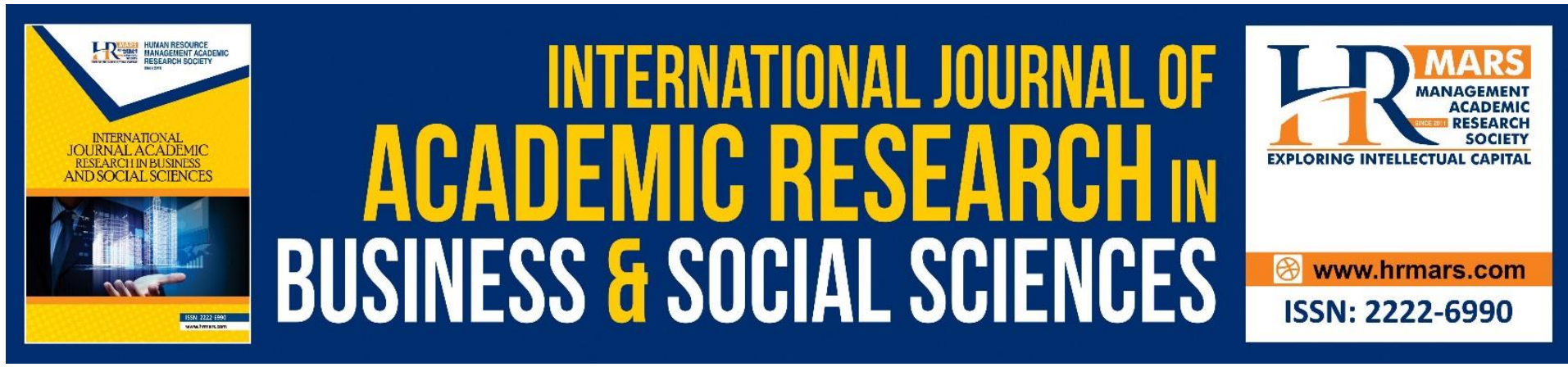

\title{
The Veil in Islam and Randa Abdel-Fattah's Does My Head Look Big in This?
}

\author{
Halimah Mohamed Ali \\ Universiti Sains Malaysia \\ Email: halimah@usm.my
}

\begin{abstract}
This essay will discuss the concept of the veil that the Muslim woman uses vis-à-vis Randa Abdel Fattah's novel Does My Head Look Big In This? (2006). It is an Australian novel published by Pan MacMillan, that won the Australian Book Industry Award and Australian Book of The Year Award for older children. The story is about a sixteen-year-old Muslim girl who lives in Australia with her parents and decides to put on the veil. It depicts her experience with her family and friends and how the decision affects her personal and public life. The novel will be discussed via excerpts from the Al-Quran in which there are the commands of Allah on Muslim women to don the hijab or headscarf. The sayings of the prophet Muhamad (pbuh), which are called the hadith, will also be used in order to discuss the concept of hijab or the veil as presented in the novel. The discussion will reveal and encompass more than the idea of the Muslim woman's veil. It will also deliberate on her day to day life and public sphere with regards to the Islamic doctrines and compare and contrast them with the Muslim woman that is presented in the novel.
\end{abstract}

Keywords: Randa Abdel-Fattah, Veil, Al-Quran, Muslim, Australian.

\section{Introduction}

Randa Abdel-Fattah is an Australian author. She is a Muslim with Palestinian and Egyptian parents. She went to a Catholic Primary school. However, the college that she attended was an Islamic College. This essay will discuss Abdel-Fattah's novel Does My Head Look Big In This? (2006) and the arguments will be supported by the verses from the Al-Quran and the hadith which are the sayings of the prophet Muhammad (pbuh). It will deliberate and reveal the ideas about the Muslim woman's veil. The Muslim woman's day to day life will also be examined as well as the public sphere that surrounds her. They will be discussed with regards to the Islamic doctrines, and compare and contrast them with the Muslim woman that is presented in the novel.

The story is about a 15 year old Muslim girl who decides to use the hijab in school and out of it. The journey that this girl is on is profound, because she lives in a Western society where the hijab is exotic to the Western eye. Her friends do not understand her decision and she faces difficulties in her social life. Thus, the objective of this study is,

- To discuss the significant of the hijab in Islam.

- To explain why a Muslim woman needs to use a hijab in public. 
- To determine Randa Abdel-Fattah's project as an Australian author and her stand as a Muslim with Palestinian and Egyptian parents.

- Discuss the Muslim woman's day to day life as well as the public sphere that surrounds her as compared to the Muslim teenager that is presented in the fiction with supporting materials from Islamic doctrines.

\section{The Public Sphere That Surrounds The Muslim Woman}

The Muslim woman wherever she lives is surrounded by a public sphere. She may live in a Muslim country or in non-Muslim countries, but she is always surrounded by a public sphere that is controlled by her Muslim society and religion, that is Islam. Most of the time religion controls the culture of the society wherever it lives.

There is a research conducted in Canada on Young Shia Muslim women and hijab by Jiwani and Rail (2010) titled Islam, Hijab and Young Shia Muslim Constructions of Physical Activity Canadian Women's Discursive. Although this research has been carried out on Shia Muslim women in Canada and does not discuss Sunni Muslim women in Australia it will be considered here in order to understand the myriad of views on hijab. It is universal knowledge that Sunni Muslims and Shia Muslims hold different views on Islam. Shia Muslims descend from Iran, and have spread to the Middle East, and South Asia. However, the majority of the world's Muslims are Sunni Muslims. The major difference between these two Muslim sects is that Sunni Muslims believe that Prophet Muhammad (pbuh) was the last prophet while the Shia Muslim's believe that Sayidina Ali, whom they refer to as Imam Ali was the last prophet. Sayidina Ali was the son-in-law and cousin of Prophet Muhammad (pbuh).

Discourse on the hijab can be found in many genres and fields. Discourse is power. Thus, discourse on hijab empowers the Muslim woman and society. Therefore, the world at large and the women that have to don the hijab will understand the act of hijab, the laws and culture that surround it better. Jiwani and Rail (2010) state, For Foucault, the exercise of power cannot be possible without discourse and the production of "truth" cannot occur without exercising power. The concept of discourse is tied to another key poststructuralist concept: subjectivity (Butler, 1997). According to Butler (1997), the subject takes form from language, gestures, speech acts, reflective processes, and other performative behavior. But this subjectivity is constituted through the (gendered, ethnicized, and racialized) discourses to which the subject has access. In addition to mapping the discourses to which young Muslim Canadian women have access when they construct their meanings of physical activity, we investigate how they position themselves in relation to these discourses, how they constitute their subjectivity within such discourses, and how they become subjects of such discourses by "subjecting" themselves to their meanings and power (Hall, 2001). (Jiwani and Rail, 2010: $254-255)$.

In this essay I will appropriate dominant discourse on the hijab that is the Al-Quran and the hadith. These two discourses are the doctrines of Islam which are important, and have to be used hand in hand when discussing Islam and passing Islamic laws and judgement. The AlQuran is a revelation from God whom the Muslims refer to as Allah. The concept of how the Al-Quran was revealed to the Prophet Muhammad (pbuh) for the Muslims, is similar to that of the Bible that was revealed to the Christians through Jesus. The hadith is a collection of the Prophet's sayings and teachings to the Muslims. It explains in detail the laws of Islam that are present in the Al-Quran. Both the texts will be discussed in the next section. 


\section{The Hijab in the Al-Quran and Hadith - The Islamic Doctrines}

The parts of the body that have to be covered by a Muslim man or woman are called aurat in Malay or aurah in Arabic. The Arabic word aurah will be used in this essay in order to describe the parts that have to be covered by a Muslim. According to Asni, (2013), in his book Rahsia Aurat Sempurna, Secara zahirnya, ALLAH SWT menyuruh hamba-NYA menutup aurat adalah kerana mahu menjaga kemuliaan manusia. Tidak menjaga adab-adab ketika bersama manusia yang lain akan membawa kerosakan kepada masyarakat (18-19).

(Externally, ALLAH SWT decrees His slaves to cover the parts of their bodies that should be covered (aurah) to safeguard the dignity of human beings. Not safeguarding courtesy when with other human beings will bring disaster to society (18-19)).

Asni, (2013) also points out the wisdom of covering the aurah. He outlines 5

wisdoms. According to him:

One of the signs that ALLAH SWT has glorified man is that he has created man and given him a good disposition (Asni, 2013: 23).

Thus, Allah has decreed hijab on men and women to cover their aurah in order to protect the gift that He has bestowed upon them, that is the gift of beauty.

1. The hijab also represents the man and woman that are pious and believe in Allah SWT. Those who believe in him and his Oneness will follow the message that has been brought down by the Prophet Muhammad (PBUH) and will adhere to the prohibitions that have been decreed by Him (Asni, 2013: 23).

2. The hijab will also help them to avoid being attacked by those with wicked hearts and can also protect them from slander (Asni, 2013: 23).

3. Society will be able to differentiate between a Muslim woman and a non- Musim woman. They will be recognized easily (Asni, 2013: 23).

4. The hijab is also able to protect women from many skin diseases. This is because Allah has bestowed upon women fine and tender skin. Therefore, it has to be protected and taken care of (Asni, 2013: 24).

The hair is also a woman's crowning glory. Its beauty attracts men to a woman. In a strange environment outside her living quarters a woman needs protection especially from strangers, who might take advantage of her beauty. The beauty of a woman does not only attract admirers but also enemies. Helen of Troy is the best example of how a country fell due to a woman's beauty. History teaches us many things if we choose to learn from it. The hijab was decreed by Allah SWT to Muslim women because beauty can destroy. Another example is Cleopatra the Queen of Egypt who was in love with Marc Anthony. Her beauty attracted the Roman nobleman, however their love could not protect Egypt from falling into Rome's hands. Thus, Muslims and Islam were given a solution by Allah SWT. The hijab is that gift from Allah to his worshippers. Although many people think it suppresses a woman, in its essence it liberates her. She does not need to show off her beauty in order to attract men. In many societies including the Western society a woman in hijab gains respect from the members of 
her society. This is due to the fact that she has taken a very brave step in covering her beauty, since women often thrive upon their beauty. The woman in hijab moves around safely amongst men most of the time and escapes sexual harassment in many societies. When a man falls in love with her it is not so much for her outer beauty, but for her inner beauty the goodness of her heart.

Below are meanings of a few surah's from the Al-Quran in which Allah SWT orders men to guard their vision as well as their private parts. Therefore, it can be deduced that the hijab is not only decreed upon women but also men. Islam guides men to lower their vision when they come across women. Only the first gazes is allowed. It also orders men to dress appropriately. A man is not allowed to show his body from the waist down until below his knees when he is in front of other men as well as women. According to Surah An-Nūr (The Light) ( Surah 24: Verse 30), which means,

Say to the believing men that they should lower their gaze and guard their modesty: that will make for greater purity for them: and God is well acquainted with all that they do (Surah 24: Verse 30).

Another verse from the same surah (Verse 31) states which means,

And say to the believing women that they should lower their gaze and guard their modesty; that they should not display their beauty and ornaments except what (must ordinarily) appear thereof, that they should draw their veils over their bosoms and not display their beauty except to their husbands, their fathers, their husbands' fathers, their sons, their husbands' sons, their brothers, their brothers' sons, their sisters' sons, or their women, or the slaves whom their right hands possess, or those male servants free of physical needs, or small children who have no sense of the shame of sex; and that they should not strike their feet in order to draw attention to their hidden ornaments. And $O$ ye Believers! Turn ye all together towards God, that ye may attain bliss. (Surah 24: Verse 31).

It is clear in the above verse what a Muslim woman can show to the public. Her hair, body and adornments are only for her husband. She can show her hair and certain parts of her body as well as adornments to her immediate family, the ones that have been outlined by Allah SWT in the verse above.

Surah Al-Ahzab (The Combined Forces) Verse 59 is Allah SWT's order to the Prophet Muhammad (pbuh) to tell his wives and daughters as well as wives of the believers and their daughters to lower their garments. They are not to show off their adornments including their hair, which has been stated above is the crowning glory of a woman. This decree was brought down by the angel Gabriel to the Prophet for his fellow Muslims in order to protect the women from abuse and to differentiate them from non-Muslim women. Allah decree's which means,

O Prophet, tell thy wives and your daughters, and the believing women, that they should cast their outer garments over their persons (when abroad): that is most convenient, that they should be known (as such) and not molested. And God is Oft-forgiving, Most Merciful. (Surah 33: Verse 59).

The discussion of hijab can also be found in a hadith narrated by Aishah, the wife of the Prophet Muhammad (saw). The hadith states, 
The wives of the Prophet used to go to Al-Manasi, a vast open place (near Baqia at Medina) to answer the call of nature at night. 'Umar used to say to the Prophet "Let your wives be veiled," but Allah's Apostle did not do so. One night Sauda bint Zam'a the wife of the Prophet went out at 'Isha' time and she was a tall lady. 'Umar addressed her and said, "I have recognized you, O Sauda." He said so, as he desired eagerly that the verses of Al-Hijab (the observing of veils by the Muslim women) may be revealed. So Allah revealed the verses of "Al-Hijab" (A complete body cover excluding the eyes) (Sahih Al-Bukhari Hadis: Hadith 1.148, http://alim.org/library/hadith/SHB/148/1)

Thus, the decree for women to don the veil came from Allah and the Prophet Muhammad's (saw) wives as well as other Muslim women had to put it on since it is part of the Islamic doctrine. However, the sin of a Muslim who does not adhere to the decree is mostly between him/her and his/her Creator.

\section{The Muslim Teenager and The Veil In The Novel}

This section is an analysis of the novel Does My Head Look Big In This? The main character, Amal Mohamed Nasrullah Abdel-Hakim is a 15 year old teenager who is attending an Australian high school. She decides to use the veil full-time, thus she has to use it to school as well. However, her school uniform does not include the hijab in it. So, she has to convince her parents and headmistress to allow her to use the veil to school. The novel is a narrative that reveals the Muslim teenager's dilemma in a Western society. It also problematizes the Muslim teenager's dilemma as to how to behave in a culture that is different from their home and religious culture. They have to uphold and assimilate both cultures in their day to day lives. Thus, Amal represents the Muslim teenager everywhere in the Western world and the problems faced by them and their emotions as well as their believes when facing Western culture and society and practicing their religious believes and culture.

Amal's emotional dilemma about putting on the veil full-time and to school is presented below. Her thoughts are revealed to us,

I was ready to wear the hijab...I can't sleep from stressing about whether I've got the guts to do it. To wear the hijab, the head scarf, full-time. "Full-timers" are what my Muslim friends and I call girls who wear the hijab all the time, which basically means wearing it whenever you're in the presence of males who aren't immediate family. "Part-timers" like me wear the hijab as part of our uniform at an Islamic school or when we go to the mosque or maybe even when we're having a bad hair day (Abdel-Fattah, 2006: 2).

From the excerpt above we know that Amal understands the rules of wearing the hijab. A Muslim woman has to don the headscarf in the presence of males who are not immediate family members. The Muslim girls are trained to respect their religious culture by their family. This is evident when the narrative states that "Part-timers" only use the hijab to Islamic schools, or to the mosque. The veil is also a tool that is used by some Muslim girls as well as women when their hair, which has been stated above is the crowning glory of a woman is ugly. It is used to hide the imperfection of their hair sometimes.

The narrative situates Amal in the text. She hails from an upper class Australian-Palestinian family. According to the text, My dad's a doctor and my mum's a dentist. Two major nerds who fell in love during their hibernations in Monash University medical library. They were 
both born in Betlehem, but there are fifty-two years of Australian citizenship between them. My Dad's name is Mohamed...My mum's name is Jamila, which means beautiful in Arabic (Abdel-Fattah, 2006: 3).

Amal's parents are Palestinians, who have become Australian citizens, living in exile since their country, Palestine was taken over by the Jews and turned into Israel. There are many Palestinians living in exile around the world, because they have lost their country and live in fear of death in their own country. One of the most famous Palestinian who lived in exile was the late Edward Said who introduced the Orientalism theory to the world in 1978 from the United States of America.

Amal describes her identity living in a Western country as a teenager well. Her confusion and difficulty living within a culture that is foreign to her own religious and cultural practice is manifested below, I'm an Australian-Muslim-Palestinian. That means I was born an Aussie and whacked with some seriously confusing identity hyphens. I'm in Year Eleven and in four days' time I'll be entering my first day of term three at McCleans. My Jennifer Aniston experience couldn't have come at a worse time. I mean, it's hard enough being an Arab Muslim at a new school with your hair tumbling down your shoulders. Shawling up is just plain psychotic (Abdel-Fattah, 2006: 6).

Amal has some doubts about putting on the veil. She describes in very few words that life for an Arab-Muslim teenager in a new school is quite difficult, and putting on the hijab would mean that it would become extra difficult. This situation faced by an Arab-Muslim female teenager in an Australian school is representative as well for the Arab-Muslim women in Australia and other Western states. Being an Arab and a Muslim after September 11, has become a very difficult task for Arab-Muslims and Muslims around the world especially in the West. Donning on the veil would mean accentuating ones Muslim identity. However, it cannot be denied that a Muslim who accentuates his or her Muslim identity in a Western world and environment after September 11 is very brave. It takes courage to stand out and declare that you are part of a society and community that is looked upon with suspicion and misgivings in the Western world and non-Muslim world because of the mistake and errant ways of a few callous Muslims. Thus, the author through Amal, a Palestinian-Arab Muslim teenage girl living in Australia, and deciding to veil herself while she is still a teenager in her formative years, shows that the Muslims are brave and do not hide behind shadows in order to avoid themselves from being associated with the perpetrators who instigated September 11. The author makes a very important statement via this novel. If the Muslim world at large was responsible for September 11, the women would have discarded their veils, and hid behind a new identity in order to run away from the scourge of September 11 that was put on the Muslims world-wide.

Amal's feelings and conviction towards Islam are portrayed to us in the novel. The excerpt below describes her feelings, I'm terrified. But at the same time I feel like my passion and conviction in Islam are bursting inside me and I want to prove to myself that I'm strong enough to wear a badge of my faith. I believe it will make me feel so close to God. Because it's damn hard to walk around with people staring at your "nappy head" and not feel kind of pleased with yourself - if you manage to get through the stares and comments with your head held high. That's when this warm feeling buzzes through you and you smile to yourself, knowing God's watching you. Knowing He knows you're trying to be strong to please Him. 
Like you're both in on a private joke and something special and warm and extraordinary is happening and nobody in the world knows about it because it's your own experience, your own personal friendship with your Creator. I guess when I'm not wearing the hijab I feel like I'm missing out. I feel cheated out of that special bond (Abdel-Fattah, 2006: 8).

We understand that Amal loves God and wants to be a good Muslim. It is a dilemma faced by many Muslim girls her age. When a Muslim girl reaches puberty, that is the day that she has her first menstrual cycle, she has to put on the headscarf, because now when she commits a sin she will be punished for it. Islam states that a child whatever his or her religion, is born without sin. He/she only has sin when he/she commits it after he/she reaches puberty. It is the parents' duty to educate the child to be a good human being whatever their religion. The hijab as Amal says is a bond between a Muslim woman and her Creator. It is a special relationship that a Muslim woman has with the God that created her. Although it is God's decree in the Al Quran for a woman to put on the veil and loose clothing once she reaches puberty, in many Muslim countries there is no external law other than the decree in the Al Quran that forces a woman to put on the hijab. Most of the time a Muslim woman does it because she realizes that it is her duty towards God. In Islam sincerity is the most important feature in a Muslim's day to day life and in his/her worship to God and in following the tenets and laws of Islam. Without it a Muslim is labelled a hypocrite. The Prophet Muhammad (pbuh) in one of his hadith's said that a hypocrite is more dangerous than a non-believer. There is a surah in the Al-Quran which is titled Surah Munafiq which means The Hypocrites. It describes what hypocrites are and the laws against them to protect believers from them.

Amal is resolute in her decision to put on the veil. However, she is also nervous. She has her doubts about her decision. According to the narrative, I'm ready for the next step. I'm sure of that. But I'm still nervous. Argh! There are a million different voices in my head scaring me off. But why should I be scared? (Abdel-Fattah, 2006: 8).

She questions her anxiety and draws a long list to make sense of her decision and give herself encouragement to take the step that she has decided on taking. She rationalizes that she is doing it in the name of Allah/God and because it has been commanded by Him that men and women should dress modestly.

After making the list to make sense of her decision and to give herself courage Amal begins to think of what her classmates are going to say about her new look, "I can't imagine what my class will say if I walk in with the hijab on (9). She then goes back in time to where she learnt about the hijab. It was indoctrinated in her from Year Seven to Year Ten at Hidaya Islamic College. Hidaya is an Arabic word which means guidance in English. Amal says, I can't stop thinking about Hidaya and I feel sick with longing for a school where you learnt what every other student in any other Melbourne school learnt but you could also pray and fast and wear a hijab and get on with being a teenager without having to answer questions or defend yourself against news headlines. Where you sang "Advance Australia Fair" every morning at assembly and got detention if you didn't take it seriously. Where you could deal with puberty and teenage angst thing and have your crushes and go through your diets without being a prefix to terrorism, extremism, radicalism, any ism (Abdel-Fattah,2006: 12). In an Islamic environment the hijab would not be much of a problem to a teenage Muslim girl who is also like any other teenage girl around the world, trying to make sense of her life. 
The narrative emphasises the idea that teenagers, whatever their religious believe will go through the same problems and doubts while growing up. They all worry about boys or girls, their weight, their skin condition and much more. Donning the hijab outside the Muslim environment takes much courage and entails a Muslim individual to be labelled an extremist, a radical or in a far worse situation, a terrorist.

When Amal informs her parents of her decision to put on the veil, they are quite surprised. Their anxiousness, doubts and Amal's persistency is depicted in the excerpt below, At dinner I tell my parents that I'm thinking about wearing the hijab and to my disbelief they look at each other nervously. I was expecting a cheerleader routine around the family room. Not two faces staring anxiously at me. "I can't believe you guys aren't even happy for me! I thought always encouraging me to pray more and talking to me about finding spirituality and all that, so why aren't you happy that I'm taking the extra step? Like you did, Mum? Huh?" "We're proud of you. But it's a big decision, honey, and you're not at Hidaya any more. It's a different environment at McCleans. It might not even be allowed" (Abdel-Fattah, 2006: 23).

Although Amal's parents are practising Muslim's as they keep to their prayers and furthermore her mother also uses the veil, they are not happy with Amal's decision. The environment in the school worries them because it is not an Islamic school, and the friends that surround Amal are mostly non-Muslims. Teenagers would not be able to understand her religious convictions and might ostracize her just because of a piece of cloth on her head.

Amal is adamant with her decision although her parents oppose it. Her reason is, "...I want to try...and I want that identity. You know, that symbol of my faith. I want to know what it means to be strong enough to walk around with it on and stick up for my right to wear it." (Abdel-Fattah, 2006: 24).

Her first taste of being part of a group, to be recognized and feel the intensity of her religious belief and practice is when she is greeted by three Muslim girls at a shopping mall. This has never happened to Amal. This represents Muslim solidarity. The Islamic greeting that is used by one of the girls identifies her with them. It is clearly represented in the excerpt below, "Assalamu Alaykom," she says, greeting me with the universal Islamic greeting, Peace be upon you. "Walaykom Wassalam," I reply, smiling back at her. The other two girls also greet me and they all smile warmly at me. They go back to their conversation and I walk off with a big grin because it is now that I think I begin to understand that there is more to this hijab than the whole modesty thing. These girls are strangers to me but I know that we felt an amazing connection, a sense that this cloth binds us in some kind of universal sisterhood (Abdel-Fattah, 2006: 28).

Amal feels empowered by her experience. She now belongs to a select group of Muslim girls and women: those who use a hijab. Her feelings are presented by the author in the next excerpt, I lie in bed that night and replay the scene over and over in my head. I'm experiencing a new identity, a new expression of who I am on the inside, but I know that I'm not alone. I'm not breaking new ground. I'm sharing something with millions of other women around the world and it feels so exciting. I know some people might find it hard to believe but walking around Chadstone tonight I'd never felt so free and sure of who I am. I felt safe that people weren't judging me and making assumptions about my character from 
the length of my skirt or the size of my bra. I felt protected from all the crap beauty and image. As scared as I was walking around the shops in the hijab, I was also walking around the shops in the hijab. I was also experiencing a feeling of empowerment and freedom. I know I have a long way to go. I still dressed to impress and I took ages to get my make-up, clothes and hijab just right. But I didn't feel I was compromising myself by wanting to make an impression. I was looking and feeling good on my own terms, and boy did that feel awesome (Abdel-Fattah, 2006: 28-29).

Amal knows that her decision will affect her future, and she is prepared to face the challenges that will come her way because of the veil that she will put on in public.

The hijab is not the only thing that makes a Muslim woman a Muslim. She has to perform the five daily prayers. A Muslim child is trained to pray when he/she is seven years old and is required to perform his/her five daily prayers at age 10 . Thus, we are shown Amal's and her parent's practice of prayers,

My dad wakes me up for morning fajr, prayer. I'm not my best at dawn and sometimes I throw the pillow and tell him to go away. But most mornings I get up with them to pray. The walk to the bathroom is always a zombie-steps experience...I perform the wudhuh, the ablution, wetting my hands, face, arms, feet and crown of my head. And then we pray. My dad leads the prayer and his voice as he reads the Koran is soft and melodious. And it's when I'm standing there this morning, in my PJs and a hijab, next to my mum and my dad, kneeling before God, that I feel a strange sense of calm. I feel like nothing can hurt me, and nothing else matters. And that's when I know I'm ready (Abdel-Fattah, 2006: 29).

We can feel how much Amal loves God. Amal and her family represent the majority of Muslims around the world. It is a sacrifice for a Muslim, to wake up very early in the morning before the sun rises to perform the first prayer of the day, the Subuh prayers. While others are sleeping Muslims perform their ablutions in the early hours of the morning disregarding the cold weather, even in winter in order to worship God.

Although in the above excerpt we are informed that Amal feels calm about her decision it does not keep her from worrying about her friends' reaction towards her decision to put on the veil. The excerpt below shows this worry,

What will they say about my hijab?"...I've just got to take the plunge; that's the only way to do it. Wear it and then deal with the consequences as they come along. It's a new term. It'll be like a fresh start for me. I feel like I'm ready but that my fears have ganged up on my confidence and grabbed it in a headlock. Every minute or so it manages to escape their clutches and come up for fresh air, but then my fears attack again and I'm stuck struggling to feel one emotion, have one stable thought, take one solid stance as the gang warfare goes on...I don't want to wear it today and then chicken out and rock up to school tomorrow without it. It's not a game or a fashion statement or a new fad. It's more serious than that" (Abdel-Fattah, 2006: 31).

Amal is worried about her friend's reaction. She does not want to discard the hijab easily because for her it is a commitment. It is not a fad or a fashion statement. Amal goes to see her headmistress Ms. Walsh to inform her of her decision to use the hijab to school. Ms Walsh thinks that Amal's parents have forced her to use the hijab. She is displeased. Her displeasure is evident in the excerpt below, "I would have spoken to you earlier except today 
is my first school day wearing it. I made the decision during the holidays." "Hmm...now let me see." She presses her fingers down on her temples. "So your parents have made you wear the veil permanently now? Starting from today? Your first day of term three. Couldn't it wait until tomorrow? After they'd spoken to me?" (Abdel-Fattah, 2006: 38).

However, Amal defends her decision and her right to use the veil. She says, "Nobody has made me wear it, Ms Walsh. It's my decision" (Abdel-Fattah, 2006: 39). Amal argues that she is not trying to rebel against the school rules. Amal has to convince her headmistress that she wanted to wear the hijab to school since she did not consult her before deciding to wear it.

After facing her headmistress about her decision to use the hijab, Amal has to face her friends. One of her friend inquires, "So let me get this right," Eileen says. "You don't have to wear it in front of family, kids and females?" Basically that's it." "So it's not like you wear it all the time," Simone says. "That's right. Of course...I wear it in the shower." Eileen and Simone roll their eyes at me. "Like we're that naïve, Amal." (Abdel-Fattah, 2006: 45).

Her friends are curious because they are not well informed about Islam and the hijab. Amal patiently explains to her friends why she is using it and why she has to don the veil. Eventually her friends accept her decision and accepts her new image without much questioning.

Amal's decision to use the hijab also means she has to be a better Muslim than she already is. One of the most important tenets in Islam are the five daily prayers. The hijab is a responsibility that a Muslim woman carries once she dons it. By putting on the veil a Muslim woman has declared her Muslim identity to her society and the world at large. Thus, she has to uphold that image and act according to the Al Quran and the sunnah (the hadith). Therefore, prayers represent that Muslim identity as well, and a Muslim woman in hijab has to perform the five daily prayers because the second item in the 5 pillars of Islam is 'Praying 5 times a day'. Amal adheres to this responsibility. The excerpt below shows this fact, I need a place to pray, so at lunch time I go to see Mr. Pearse. All through the year I've been carrying out my two afternoon prayers at home after school but l'd go through them at supersonic speed so that I could make it in time to watch Home and Way. It never felt right and now I really want to try to pray at the set times, the way it's supposed to be (AbdelFattah. 2006: 46).

Amal tries to adhere strictly to Islamic tenets. However, this does not turn her into an extremist who shuns worldliness in order to embrace religion and God. She still wants to watch television which is quite worldly. Some Muslims leave this world totally like Roman Catholic nuns used to in order to be nearer to God. Amal represents the modern Muslim teenager in many Western countries and Westernized nations. She leads a balanced life and loves both modernity and religion.

\section{Conclusion}

Randa Abdel-Fattah's Does My Head Look Big In This is a novel that educates the West as well as the Muslims about the value of the hijab and a Muslim woman's responsibility towards herself and her religion. Abdel-Fattah emphasises the fact that the hijab does not hinder a Muslim female from doing worldly things. Extremism is not a Muslim identity. A Muslim male or female has to have a balanced character and identity. They have to adhere 
to Muslim laws but at the same time they have to live in this world and uphold modernism and new ideas which do not go against the tenets of Islam, because Islam upholds education, modernity, new ideas and humanity as well. The veil does not hinder a woman to practice a modern day-to-day life.

Amal's public sphere is dual in form - current day Australia and her Islamic background and family. She follows the Islamic doctrine, since she has been educated by her parents in an Islamic school in the beginning and in a practicing Muslim environment. Her decision to put on the hijab is very much influenced by this. The narrative is successful in its project to educate the readers that it is up to a Muslim woman eventually to decide whether she wants to don the veil or not. With the help of an Islamic framework this essay has managed to explain the purpose of the veil in Islam and Abdel-Fattah's project. The dominant discourse is Islam and a Muslim teenager's quest in upholding her religious practice although she might have problems living in a predominantly White-Christian society. Abdel-Fattah manages to point out that the veil does not hinder a Muslim woman to lead a normal Westernized life.

This research has contributed to two fields, sociology and the humanities. It contributes towards Islamic knowledge and World Literature. It explicates theoretical perimeters that concern the Muslim woman and hijab which involve Islamic jurisprudence that is explained through the Al-Quran and the hadith as well as Muslim religious texts. This research has contributed in explaining why a Muslim woman needs to use the hijab and in which verses in the Al-Quran it is stated that she has to don the hijab. How the hijab has to be put on and which parts of the body have to be covered are also explained through the hadith and Islamic knowledge. This research confirms that Islamic theory and knowledge of the hijab go hand with the reading of fiction that deal with issues that concern Islamic jurisprudence. The theory used in this reading is Islamic and the context is Australian Literature with regards to the Muslim world and worldview.

\section{References}

Randa, A. F. (2006). Does My Head Look Big In This? Marion Lloyd Books.

Tanzeel, A. (2006). Does my head look big in this? http://www.asiansinmedia.org/news/article.php/publishing/1344.

Yusof, A. A. (Trans.) (2013) (1998). The Holy Quran: Original Arabic Text. Saba Islamic Media.

Sarah, B. (2013). Does My Head Look Big In This? http://suite101.com/article/does-my-head-lookbig-in-this-a220369 online 12/08/2013

Claussen, T. (2011). The hijab - secularity and beyond: Analysing debates on cultural diversity (hijab) through classical social science theory. 2nd International Conference on Humanities, Historical and Social Science IPEDR. 17, 190-194

Hammami, R. (1990). Women, the Hijab and the Intifada . Middle East Report, No. 164/165, Intifada Year Three (May - Aug., 1990), pp. 24- 28+71+78 Published by: Middle East Research and Information Project Stable. http://www.jstor.org/stable/3012687.

Hanzaee, K. H., Chitsaz, S. (2011). A review of influencing factors and constructs on the Iranian women's Islamic fashion market. Interdisciplinary Journal of Research in Business. 1 (4), 94-100.

Jiwani, N. R., Genevieve, R. (2010). Islam, Hijab and Young Shia Muslim 
Constructions of Physical Activity Canadian Women's Discursive. Sociology of Sport Journal, 27, 251-267.

Laborde, C. (2006). Female Autonomy, Education and the /hijab. Critical Review of International Social and Political Philosophy. 9 (3), 351-377.

Asni, M. F. A. (2013). Rahsia Aurat Sempurna. Grup Buku Karangkraf Sdn.Bhd.

Ruby, T. F. (2006). Listening to the voices of hijab. Women's Studies International Forum, 29, 54-66. www.elsevier.com/locate/wsif.

Usman, M. M. T. (2010). The Hijab of Women and its Boundaries. In Dress, Featured, Hadith Commentary. Women's Issues.

http://www.deoband.org/2010/06/hadith/hadith-commentary/the-hijab-of-womenand-its-boundaries/ 


\section{Author Biography}

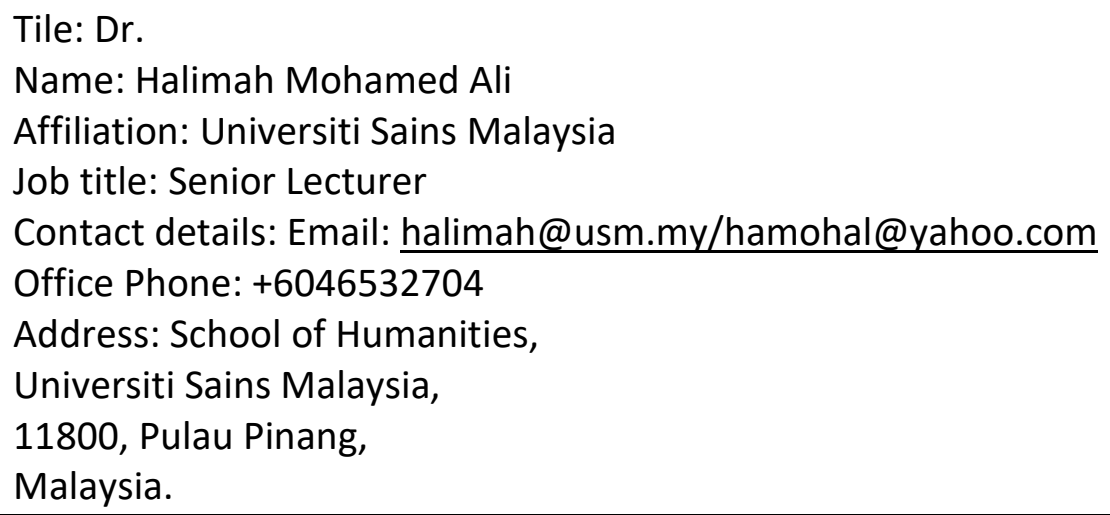

She is a Senior Lecturer. Her expertise are British and Comparative Studies (Literature and Theory), Orientalism from Within, Shakespeare in Performance, Rhetoric and Philosophy and Postcolonialism as well as Mass Communications and Public Relations. Her recent essay is titled Bollywood Audio-visual Responses towards 9/11 Through Kurbaan and My Name is Khan. Nukhbak Taj Langah (ed). 2019. Literary and Non-Literary Responses Towards 9/11: South Asia and Beyond. Routledge. 